\title{
THE MODULATORY EFFECT OF DIETARY BETAINE ON INTESTINAL ABSORPTIVE CAPACITY, LIPOGENESIS AND EXPRESSION OF LIPID METABOLISM- AND GROWTH-RELATED GENES IN NILE TILAPIA FED ON SOYBEAN MEAL-BASED DIET
}

\author{
Taha Ismail ${ }^{1}$, El-Desoky Nassef ${ }^{1}$, El-Sayed Hegazi ${ }^{1}$, Abdel-Nasser Bakr $^{1}$, \\ Eman M. Moustafa ${ }^{2 *}$, Walied $\mathrm{Abdo}^{3}$, Zizy I. Elbialy ${ }^{4}$
}

\begin{abstract}
${ }^{1}$ Department of Nutrition and Clinical Nutrition, Faculty of Veterinary Medicine, Kafrelsheikh University, Egypt. 'Department of Fish Diseases and Management, Faculty of Veterinary Medicine, Kafrelsheikh University. ${ }^{3}$ Department of Pathology, Faculty of Veterinary Medicine, Kafrelsheikh University. ${ }^{4}$ Department of Fish Processing and Biotechnology, Faculty of Aquatic and Fisheries Sciences, Kafrelsheikh University
\end{abstract}

*Corresponding author, E-mail: emantarek2002@yahoo.com

\begin{abstract}
The current experiment was randomly designed in a $2 \times 2$ factorial design. Two dietary protein sources were utilized; fish meal and soybean meal; with betaine incorporation to both of them. This study aimed to determine the impact of incorporation of betaine into soybean meal-based (SBM) diets through its effects on growth performance, intestinal healthiness and expression of some lipid metabolism- and growth-related genes. Fish $(19.84 \pm 0.20 \mathrm{~g}$ ) were stocked in 12 aquaria and allotted into triplicate four groups (10 fish per aquarium). Four test diets were formulated to contain fish meal (FM) as a positive control, FM with betaine (FM + Betaine), SBM diet and SBM with betaine (SBM + Betaine), respectively. After 60 days, dietary betaine improved the growth performance of fish fed FM or SBM as revealed by higher final body weight, body weight gain and average daily gain and lower feed conversion ratio. Monitoring the whole-body composition revealed that addition of betaine to diet relatively augmented flesh protein content and reduced its fat content. In addition, betaine incorporation in diets significantly $(P<0.05)$ increased the intestinal villi length especially in the jujenal portion as well as the numbers goblet cells. Furthermore, betaine had a downregulating effect on expression of lipid metabolism-related genes, fatty acid synthetase (Fas) and lipoprotein lipase ( $L p /$ ) and upregulating effect on insulin growth like factor-1 (Igf-1) gene in liver. It could be concluded that dietary supplementation of betaine incorporation to soybean-based diets enable nutritionists to substitute FM in fish diet. Also, betaine could improve growth performance, carcass quality (through increasing protein and decreasing lipid in fish) and enhance intestinal functions capability.
\end{abstract}

Key words: Betaine; growth performance; insulin like growth hormone factor; lipid metabolism related genes; Nile tilapia; soybean meal protein worldwide, particularly for African 
people (1-3). Natural fisheries are progressively exhausted and the aquaculture end up basic means to compensate the need in this fundamental wellspring of dietary protein (4). Along these lines, to repay the insufficiency in animal protein resulted from the expanded interest for fish as human sustenance, fish farming is quickly extending everywhere throughout the world (5). Aquaculture contributes the greater part of the overall fish production all over the world. In Egypt, the aquaculture industry gives about $77 \%$ of the all national fish production providing arround one million ton annually (6$8)$. Progressive enhancement of this industry must be correlated with corresponding improvement of fish feed quality representing $70 \%$ of the total culturing costs $(7,9)$.

Nile tilapia (Oreochromis niloticus) represents the most prevalent freshwater fishes in Egypt, widely cultured because of its high growth rate, cheap price, palatability, ability to withstand stress and diseases, ability to spawn easily and the minimal requirements in regard to management and energy inputs (10). Heightening of aquaculture production frameworks exposes fish to various ecological stressors like; poor water quality, over-crowdness, improper handling and transport which may contrarily influence their growth and health, as well as limiting the outcome of aquaculture systems (11).

Nutrition assumes as a basic job in the growth, advancement and prosperity upkeep of fish (12). Years ago, fish meal was used as the basic protein source in tilapia diets (13). Due to the extending cost and unreliable supply of this ingredient, numerous attempts have been admitted to upgrade the growth performance and decrease the production costs of cultured tilapia through replacement of fish meal with another protein sources either from terrestrial animals or plants. This was done by utilization of probiotics or prebiotics as safe dietary supplements which have neither residue in the cultured fish nor harmful impacts for fish consumers (1415). However, increasing amount of the fish meal alternatives in the diet may result in decreasing the diet palatability to fish; decreasing feed intake and subsequently decreasing fish growth rate (16).
Betaine (trimethylglycine) is synthetized from choline oxidation (17), present in most organisms and is fundamentally extracted from sugar beet processing (18). Interestingly, betaine was recorded to improve growth performance, fish health status, feed digestibility as well as flesh quality and immune status of fish species $(19,20)$. It was used as a feed attractant and appetizer through stimulating the olfactory bulb, increasing feed intake and minimizing the feed wastage and water pollution (21). In addition, betaine can play a role in the osmoregulation through increasing both water retention of perturbed cells and cytoplasmic osmotic pressure via raising the temperature and ionic tolerance of critical enzymes and cellular membranes that results in protection of intracellular enzymes against osmotically or temperature induced inactivation $(22,23)$. Moreover, betaine acts as a methyl donor so it plays a great vital role in energy metabolism and synthesis of methionine, carnitine, phosphatidyl choline, creatine and protein $(24,25)$. Betaine plays a fundamental role in lipid metabolism suggesting that it is a lipotropic factor having a hepatoprotective function (26-28). Dietary betaine additionally has the ability to reduce body lipid deposition $(29,30)$.

To the best of our knowledge, there is little published data on the supplemental effects of betaine on growth performance, intestinal absorptive capacity, intestinal morphometry, lipid metabolism and growth-related genes in Nile tilapia (O. niloticus). Thus, the current study was conducted to role out the effect of incorporation of betaine to soybean-based diets and to assess its effects on growth performance, intestinal absorptive capacity, and expression of lipid metabolism- and growth-related genes in Nile tilapia.

\section{Material and methods}

The feeding trials were carried out at the $\mathrm{Nu}$ trition and Clinical Nutrition Department, Faculty of Veterinary Medicine, Kafrelsheikh University, Egypt, for 10 weeks during 2018. Animal ethics committee, Faculty of Veterinary 
Medicine, Kafrelsheikh University, Egypt; affirmed and approved the protocol and conducting of the study.

\section{Preparation of the experimental diets}

Two basal diets were formulated to be isonitrogenous and isocaloric in terms of crude protein $(30 \%)$ and digestible energy $\left(3.05 \mathrm{kcal} \mathrm{g}^{-1}\right)$. Each diet was based on either fish meal (FM) or soybean meal (SBM) as the main source of dietary protein. Then each diet was supplemented with $2 \mathrm{~g}$ betaine per $\mathrm{kg}$ diet (FM, FM+betaine, SBM and SBM+betaine) (Table 1) as suggested by Luo et al., (31). Betaine was purchased from Biochem Ltd. Company, Egypt and incorporated to the diets after firstly mixed with dicalcium phosphate, limestone, salts and premix until the mixture became homogenous and finally added to the other finely ground concentrate with stirring. Proximate chemical analysis of diets was performed according to Association of Official Analytical Chemists methods as shown in (Table 2).

\section{Experimental design}

The experiment was randomly designed in a $2 \times 2$ factorial design. Two dietary protein sources were used with betaine incorporation to both of them. Thus, a total of four treatments run in triplicate were allotted into12 glass aquaria $(60 \times 40 \times 30 \mathrm{~cm})$ provided with a constant aeration.

One hundred and twenty healthy Nile tilapia (O. niloticus) (initial body weight, $19.84 \pm 0.20$ g) were obtained from a private farm in Kafrelsheikh governorate, Egypt. Prior to the experiment, fish were acclimatized to basal diet for 2 weeks. At the beginning of the experiment, fish $(n=10)$ were stocked into each glass aquaria, and each diet was assigned to triplicate aquaria. Fish were fed till apparent satiation twice daily (at 9 a.m. and 5 p.m.) for 60 days and weighted every ten days in order to determine the growth and healthy status. Water parameters were monitored twice a week using water analysis device (Lamotte device, USA). Temperature ranged from $\left(24-26^{\circ} \mathrm{C}\right), 6 \mathrm{mg} \mathrm{L}^{-1}$ dissolved oxygen, $6.5-7 \mathrm{pH}$, ammonia adjusted to the normal permissible limits $(<0.1 \mathrm{mg}$ total ammonia) and $14 \mathrm{~h}$ of light and $10 \mathrm{~h}$ of dark photoperiod with $40 \%$ daily water change.

\section{Proximate chemical analysis}

At the end of the feeding trial, fish were starved for $24 \mathrm{~h}$, harvested and weighed individually then euthanized through over anesthetization using MS222 as a local anesthetic drug. 4 fish from each group were stored at $\left(-20^{\circ} \mathrm{C}\right)$ for proximate chemical analysis of fish tissue. Moisture content was carried out by drying the samples in a hot air oven at $60^{\circ} \mathrm{C}$ for $48 \mathrm{~h}$. Ash content was determined by samples incineration at $550^{\circ} \mathrm{C}$ for $6 \mathrm{hrs}$. Crude protein $(\mathrm{N} \times 6.25)$ was assessed using the Kjeldahl method after acid digestion. Fat and fiber were determined using ANKOM Technology Method.

\section{Morphometrical examination}

Snippets of the different intestinal portions were sampled from another four fish and immediately fixed in a Bouin solution for histological observations. Fixed samples were subjected to dehydration through ascending grades of alcohol solution series (70 to $100 \%$ ). After dehydration process, tissues were deparafinized in xylene, embedded in paraffin, sectioned $(5 \mu \mathrm{m})$ and stained with hematoxylin and eosin (H\&E). The heights of intestinal villi in all parts were measured using ImageJ version 1.36 (National Institutes of Health). Mean villus height for each section was based on an average of 10 villus heights/section. Goblet cells No. was determined according to the equation: goblet cell number $=$ goblet cell number in 8 fields of $\mathrm{x} 200$ magnification power / total area examined per each fish, and was expressed as (No. of goblet cells $/ \mathrm{mm}^{2}$ )

\section{Quantitative real-time PCR ( $q R T$-PCR)}

Liver samples were collected, quickly frozen in liquid nitrogen then kept at $-80^{\circ} \mathrm{C}$ for gene expression analysis, then total RNA was extracted from $50 \mathrm{mg}$ of liver tissue ( $\mathrm{n}=3$ /group) using TRIzol reagent (easy-RED ${ }^{\mathrm{TM}}$, iNtRON Biotechnology). RNA quality was verified using formol gel electrophoresis examination. The cDNA was synthesized from each RNA sample $(2 \mu \mathrm{g})$ using SensiFAST ${ }^{\text {TM }}$ cDNA syn- 
thesis kit (Bioline, United Kingdom). As presented in Table (3), gene specific primers of fatty acid synthase (Fas), lipoprotein lipase $(L p l)$, and insulin like growth factor-1 (Igf-1), were used to determine the expression in liver tissue and $\beta$ actin was selected as a reference gene for normalization of gene expression. Real time PCR (qPCR) was carried out using SYBR $^{\circledR}$ Premix and Stratagene MX3000 qPCR system. The reaction mix consisted of a $2 \mu 1$ cDNA sample, $12.5 \mu \mathrm{S} \mathrm{SYBR}{ }^{\circledR}$ Premix Ex TaqTM, $0.25 \mu 1$ PCR forward/reverse primers $(10 \mu \mathrm{M})$, and $10 \mu \mathrm{l}$ nuclease-free water. The thermo-cycling conditions for the reaction were as follows: $95^{\circ} \mathrm{C}$ for $5 \mathrm{~min}$, followed by $40 \mathrm{cy}-$ cles consisting of $95^{\circ} \mathrm{C}$ for $10 \mathrm{~s}$, annealing for $15 \mathrm{~s}$ at primer specific annealing temperature. Dissociation curve analyses were performed beginning at $65^{\circ} \mathrm{C}$ and ending at $95^{\circ} \mathrm{C}$, with incremental increases of $0.5^{\circ} \mathrm{C}$ every $5 \mathrm{~s}$ to validate the specificity of the PCR products. All samples were run in duplicate. Relative gene expression levels were evaluated using $2^{-\Delta \Delta \text { ct }}$ as previously described (32).

\section{Calculations and statistical analysis}

The following variables were calculated:

Total body weight gain $(\mathrm{TWG})(\mathrm{g} / \mathrm{fish})=$ final body weight (W2) - initial body weight (W1).

Average daily gain $(\mathrm{ADG})=(\mathrm{W} 2-\mathrm{W} 1) / \mathrm{t}$ (experiment duration $=60$ days $)$

Feed intake $\left(\mathrm{FI}, \mathrm{g}\right.$ fish $^{-1} 60$ days $\left.^{-1}\right)=($ offered feed - feed refusal recovered and dried)/number of fish

Feed conversion ratio $(\mathrm{FCR})=$ feed intake $(\mathrm{g}) /$ weight gain $(\mathrm{g})$.

The results were presented as mean \pm standard error (SE) of three replicates. All results were analyzed by one-way analysis of variance (ANOVA). When ANOVA identified differences between groups, multiple comparisons among means were made with Duncan's new multiple range test. Differences were considered significant at $(P<0.05)$. All statistical analyses were performed using the SPSS 24.

\section{Results}

\section{Growth performance}

As shown in table (4), addition of betaine to diets based on soybean meal protein significantly $(P<0.05)$ increased the feed intake. Fish fed on FM+betaine showed the highest FBW and BWG followed by that fed on SBM+betaine. Also, supplementation of betaine significantly $(P<0.05)$ increased FBW and BWG in fish fed $\mathrm{SBM}+$ betaine as compared to fish fed SBM only. FCR was markedly decreased in fish fed on FM+ betaine or SBM+ betaine when compared to the other groups. Also, FI significantly differed according to the source of dietary protein either from FM or SBM-based diet.

\section{Whole body chemical composition}

Analysis of whole-body composition presented in table (5) showed that crude protein content was significantly $(P<0.05)$ increased by addition of betaine either with FM or SBM diets. FM+ betaine showed relatively higher $\mathrm{CP}$ content than other experimental treatments. Fat content was significantly $(P<0.05)$ decreased by addition of betaine to fish diets. There were no significant differences in moisture, ash, soluble carbohydrate and ADF content among all dietary treatments.

\section{Assessment of intestinal absorptive capacity}

Duodenal, jujenal and ileal villi morphometry were showed in (Table 6) and illustrated in (Fig. 1). Betaine significantly increased the intestinal absorptive capacity of fish supplemented with FM diet $(P<0.05)$, while, SBM markedly decreased intestinal villi parameters in comparison with fish supplemented with FM diet. Interestingly, supplementation of betaine improved the jujenal villi length in FM and SBM groups. Also, the number of goblet cells per area along the intestinal mucosal lining was increased in fish fed FM diets than fish fed with SBM as a protein source. Incorporation of betaine with SBM demonstrated marked restore of goblet cells like FM diet. 
Expression of Fas, Lpl and Igf-I genes in liver tissue

Relative mRNA expression of Fas, $L p l$, Igf1 genes in liver of Nile tilapia fed on different protein sources with and without addition of betaine was shown in Figure 3. Hepatic Fas and $L p l$ mRNA levels showed upregulation in fish fed on the diets deprived from betaine $(P<0.05)$. Interestingly, addition of dietary betaine to either fish meal or soybean-based diets markedly decreased Fas and $L p l$ mRNA levels $(P<0.05)$. Fish fed on $\mathrm{FM}+$ betaine had significantly $(P<0.05)$ higher hepatic Fas mRNA level as compared to fish fed $\mathrm{SBM}+$ betaine. Igf-I mRNA level in the liver of Nile tilapia fed on dietary betaine with SBM was significantly $(P<0.05)$ upregulated as compared to fish fed SBM only. Fish fed diet with FM+ betaine showed significantly $(P<0.05)$ higher hepatic Igf- 1 expression than other groups.

Table 1: Diets formulation and experimental design

\begin{tabular}{lllll}
\hline Item (\%) & FM & FM+ betaine & SBM & $\begin{array}{l}\text { SBM+ beta- } \\
\text { ine }\end{array}$ \\
& & & & - \\
FM & 35.5 & 35.5 & - & -56.5 \\
SBM & - & - & 6.7 & 6.6 \\
Wheat bran & 3.8 & 3.7 & - & - \\
Rice polishing & 16 & 16 & 25 & 25 \\
Corn grains & 25 & 25 & 4.96 & 4.86 \\
Wheat middling & 18.9 & 18.8 & 1.2 & 1.2 \\
Soya oil & - & - & 1.8 & 1.8 \\
Fish oil & - & - & 0.33 & 0.33 \\
Nacl & - & - & 0.05 & 0.05 \\
Minerals ${ }^{2}$ & 0.05 & 0.05 & 0.05 & 0.05 \\
Vitamins & 0.05 & 0.05 & 0.1 & 0.1 \\
Vitamin C & 0.1 & 0.1 & 2.4 & 2.4 \\
Dicalcium phosphate & - & - & - & - \\
Limestone & - & - & - & - \\
Lysine hydrochloride & - & - & 0.31 & 0.31 \\
DL methionine & - & - & 0.1 & 0.1 \\
Antimycotoxin & 0.1 & 0.1 & 0.5 & 0.5 \\
CMC & 0.5 & 0.5 & - & 0.2 \\
Betaine & - & 0.2 & & \\
\hline
\end{tabular}

${ }^{1}$ Minerals (Egypt pharma company) each $5 \mathrm{kgs}$ of this product provide the following: $5000 \mathrm{mg}$ Copper; $5 \mathrm{mg}$..Cobalt; 5000 mg..Iodine; 100 mg..Selenium; $30000 \mathrm{mg}$ Iron; $40000 \mathrm{mg}$ magnesium; $10000 \mathrm{mg}$ manganese; $150000 \mathrm{mg}$ Zinc; Calcium carbonate ad to $1000 \mathrm{gm}$.

${ }^{2}$ Vitamins (Egypt pharma company) each 5 kilograms of this product provide the following: 5000000 IU Vit.A; 1000000 IU Vit. D3; $50000 \mathrm{mg}$ Vit. E; $10000 \mathrm{mg} \mathrm{K3;} 20000 \mathrm{mg}$ B1; $20000 \mathrm{mg} \mathrm{B2;} 20000 \mathrm{mg}$ B6; $20 \mathrm{mg} \mathrm{B12;} 100000$ mg Niacin; 5000 mg Folic; $100 \mathrm{mg}$ Biotin; $50000 \mathrm{mg}$ Pantothenic Acid; Calcium carbonate ad to $1000 \mathrm{gm}$. 
Table 2: Proximate chemical analysis of the basal diets

\begin{tabular}{lll}
\hline & FM & SBM \\
\hline DE (Kcal/kg) & 3045 & 3059 \\
CP \% & 29.9 & 29.92 \\
Fat \% & 6.25 & 3.6 \\
ADF \% & 6.57 & 7.17 \\
Ca \% & 1.9 & 0.7 \\
Total P \% & 1.35 & 1.02 \\
Available p \% & 0.71 & 0.46 \\
Na \% & 0.15 & 0.15 \\
Lysine \% & 1.98 & 1.67 \\
Methionine \% & 0.75 & 0.73 \\
Threonine \% & 1.18 & 0.99 \\
Tryptophane \% & 0.31 & 0.24 \\
\hline
\end{tabular}

ADF: Acid detergent fiber $\quad$ DE: digestible energy

CMC: Carboxy-methyl cellulose FM: Fish meal.

SBM: Soybean meal

Table 3: Primer sequences used for qPCR analysis

\begin{tabular}{llll}
\hline Gene & Primer sequence (5'-3') & $\begin{array}{l}\text { Annealing } \\
\text { Temperature }\end{array}$ & References \\
\hline Fas & F: TGAAACTGAAGCCTTGTGTGCC & $60^{\circ} \mathrm{c}$ & Tian et al., (33) \\
& R: TCCCTGTGAGCGGAGGTGATTA & & \\
Lpl & F: TGCTAATGTGATTGTGGTGGAC & $59^{\circ} \mathrm{c}$ & Tian et al., (33) \\
& R: GCTGATTTTGTGGTTGGTAAGG & & \\
Igf-I & F: TCCTGTAGCCACACCCTCTC & $60^{\circ} \mathrm{c}$ & Costa et al., (34) \\
& R: ACAGCTTTGGAAGCAGCACT & & Qiang et al., (35) \\
& F: CCACACAGTGCCCATCTACGA & $63^{\circ} \mathrm{c}$ &
\end{tabular}

Fas: fatty acid synethase $\quad L p l$ : lipoprotein lipase $\quad I g f-1$ : insulin like growth factor-1. 
Table 4: Effect of dietary betaine on growth parameters of Nile tilapia fed on FM and soybean.

\begin{tabular}{ccccccc}
\hline & IW $(\mathrm{g})$ & FBW $(\mathrm{g})$ & BWG $(\mathrm{g})$ & ADG $(\mathrm{g})$ & FI $(\mathrm{g})$ & FCR \\
\hline FM & $19.95 \pm 0.21$ & $50.07 \pm 0.42^{\mathrm{b}}$ & $30.11 \pm 0.27^{\mathrm{b}}$ & $0.50 \pm 0.00^{\mathrm{b}}$ & $48.68 \pm 0.52^{\mathrm{a}}$ & $1.62 \pm 0.03^{\mathrm{b}}$ \\
FM+ betaine & $19.62 \pm 0.13$ & $54.61 \pm 0.33^{\mathrm{a}}$ & $34.99 \pm 0.20^{\mathrm{a}}$ & $0.58 \pm 0.00^{\mathrm{a}}$ & $50.24 \pm 0.25^{\mathrm{a}}$ & $1.44 \pm 0.00^{\mathrm{c}}$ \\
SBM & $19.90 \pm 0.19$ & $43.17 \pm 0.54^{\mathrm{c}}$ & $23.27 \pm 0.73^{\mathrm{c}}$ & $0.39 \pm 0.01^{\mathrm{c}}$ & $42.67 \pm 0.77^{\mathrm{b}}$ & $1.84 \pm 0.03^{\mathrm{a}}$ \\
SBM+ betaine & $20.00 \pm 0.08$ & $51.16 \pm 0.30^{\mathrm{b}}$ & $31.16 \pm 0.34^{\mathrm{b}}$ & $0.52 \pm 0.01^{\mathrm{b}}$ & $49.29 \pm 0.55^{\mathrm{a}}$ & $1.59 \pm 0.01^{\mathrm{b}}$
\end{tabular}

IW: Initial weight FBW: Final body weight BWG: Body weight gain

ADG: Average daily gain FI: Feed Intake FCR: Feed Conversion Ratio.

$* *$ Values are means \pm standard error $(\mathrm{n}=10)$. Means with different small letter in the same column differ significantly $(P<0.05)$.

Table 5: Effect of dietary betaine on whole-body composition of Nile tilapia fed on FM and soybean

\begin{tabular}{lcccccc}
\hline & Moisture $\%$ & CP\% & Fat $\%$ & Ash\% & $\begin{array}{c}\text { Soluble carbo- } \\
\text { hydrates } \%\end{array}$ & ADF\% \\
& & & & & & \\
\hline FM & $57.83 \pm 0.30$ & $18.78 \pm 0.17^{\mathrm{cb}}$ & $15.80 \pm 0.15^{\mathrm{a}}$ & $2.76 \pm 0.17$ & $3.49 \pm 0.54$ & $1.35 \pm 0.17$ \\
FM+ betaine & $57.92 \pm 0.29$ & $19.85 \pm 0.15^{\mathrm{a}}$ & $14.82 \pm 0.36^{\mathrm{ab}}$ & $2.79 \pm 0.3$ & $3.37 \pm 0.41$ & $1.25 \pm 0.10$ \\
SBM & $58.2 \pm 0.31$ & $18.52 \pm 0.4^{\mathrm{b}}$ & $15.33 \pm 0.21^{\mathrm{b}}$ & $2.79 \pm 0.31$ & $3.61 \pm 1.07$ & $1.48 \pm 0.10$ \\
SBM+ betaine & $57.62 \pm 0.28$ & $19.35 \pm 0.34^{\mathrm{ab}}$ & $14.59 \pm 0.18^{\mathrm{b}}$ & $2.87 \pm 0.43$ & $4.53 \pm 0.71$ & $1.04 \pm 0.08$ \\
\hline
\end{tabular}

CP: crude protein ADF: acid detergent fiber.

**Values are means \pm standard error $(n=4)$. Means with different small letter in the same column differ significantly $(P<0.05)$.

Table 6: Effect of dietary betaine on of intestinal villi length of Nile tilapia fed on plant and animal protein sources

Treatments

\begin{tabular}{cc} 
& Duodenum \\
\hline FM & $290.69 \pm 18.16$ \\
FM+ betaine & $351.20 \pm 32.03$ \\
SBM & $278.73 \pm 23.06$ \\
SBM+ betaine & $290.18 \pm 31.43$
\end{tabular}

Villi Length $(\mu \mathrm{m})$

Jujenum

$\begin{array}{ll}530.35 \pm 30.93^{\mathrm{bc}} & 355.98 \pm 30.05^{\mathrm{a}} \\ 684.92 \pm 26.96^{\mathrm{a}} & 414.96 \pm 37.16^{\mathrm{a}} \\ 465.48 \pm 24.04^{\mathrm{c}} & 220.44 \pm 19.76^{\mathrm{b}} \\ 605.62 \pm 43.47^{\mathrm{ab}} & 255.62 \pm 30.66^{\mathrm{b}}\end{array}$

Values are means \pm standard error $(\mathrm{n}=4)$. Means with different small letter in the same column differ significantly $(P<0.05)$. 


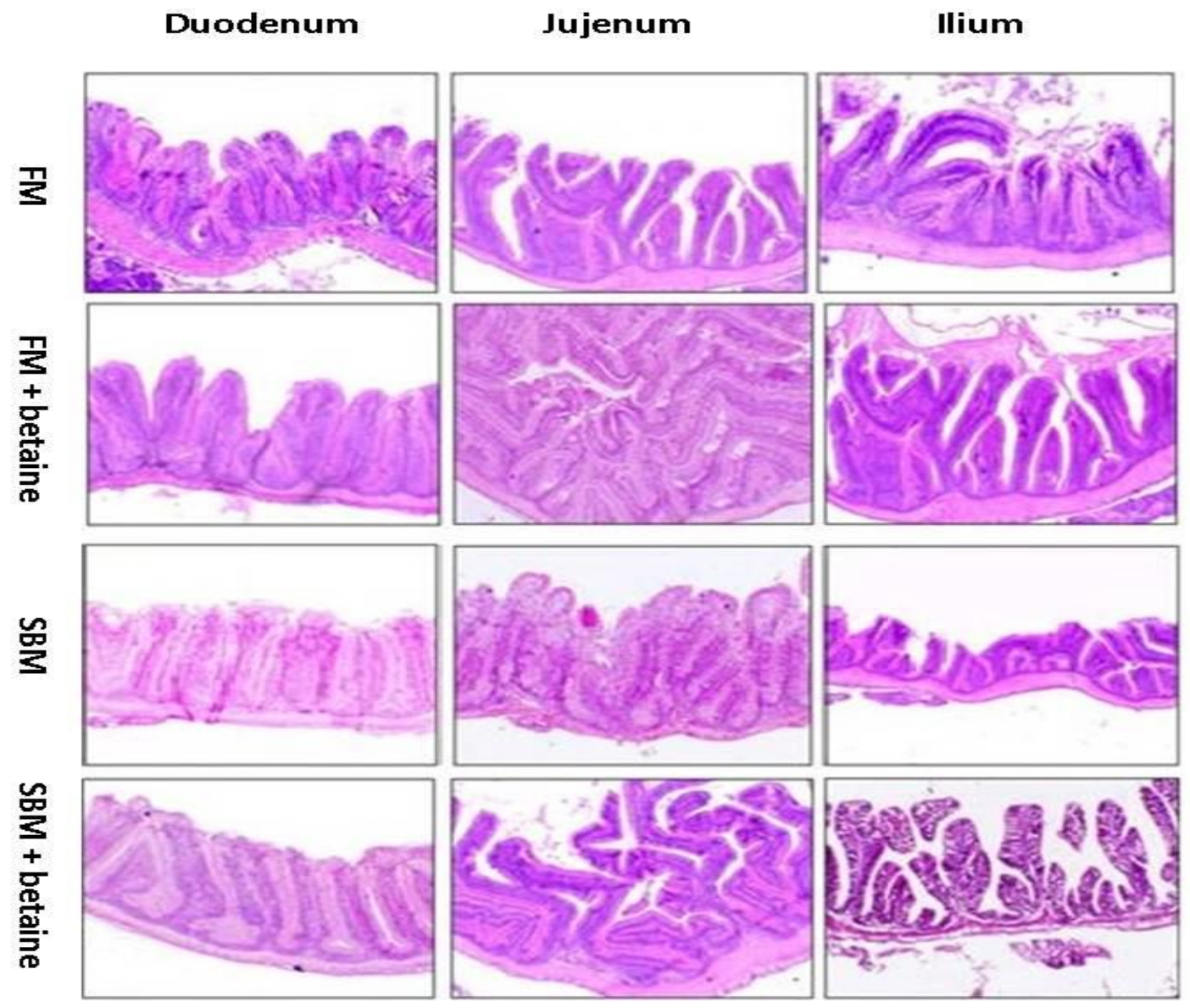

Figure 1: Haematoxylin \& eosin stained photomicrograph, assessed the effect of dietary betaine on the duodenal, jujenal and ileal villi length $(\mu \mathrm{m})$ of Nile tilapia fed on soybean meal and fish meal for 60 days

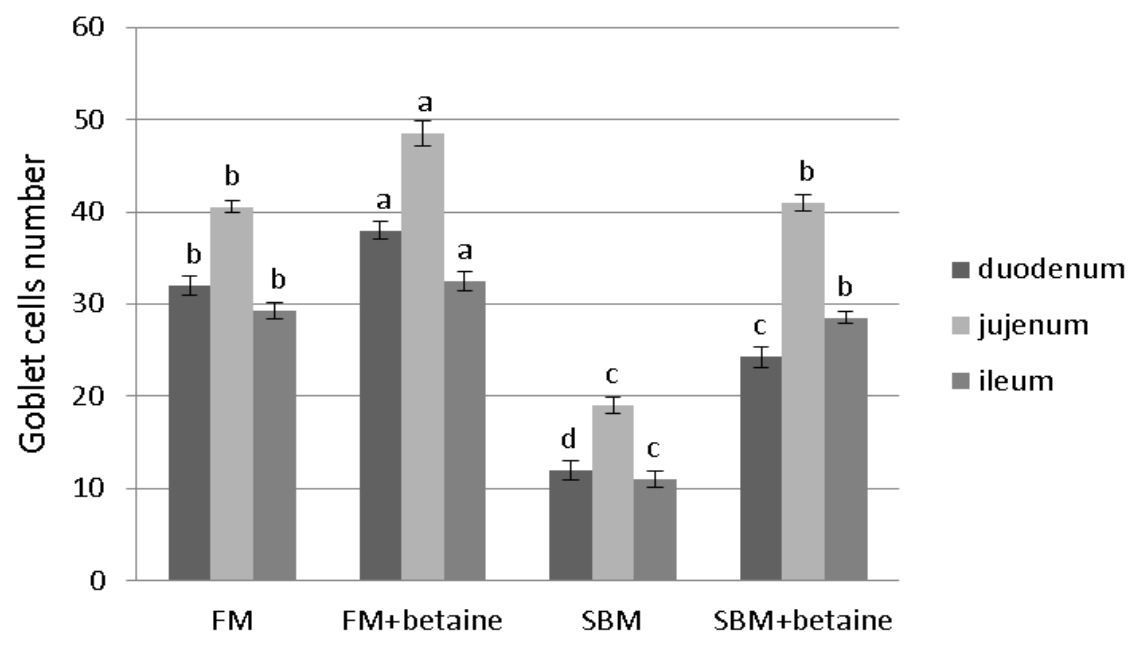

Figure 2: Effect of dietary betaine on intestinal goblet cells number of Nile tilapia fed on soybean meal and fish meal. Values are means \pm standard error $(n=4)$. Means with different small letters on columns for each organ differ significantly $(P<0.05)$ 
(a)

Fas

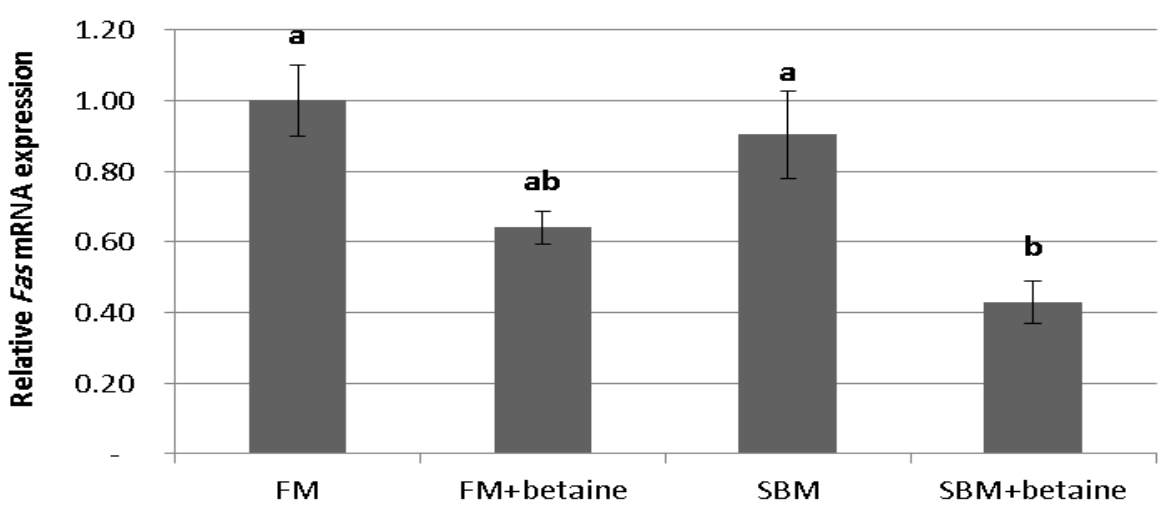

(b)
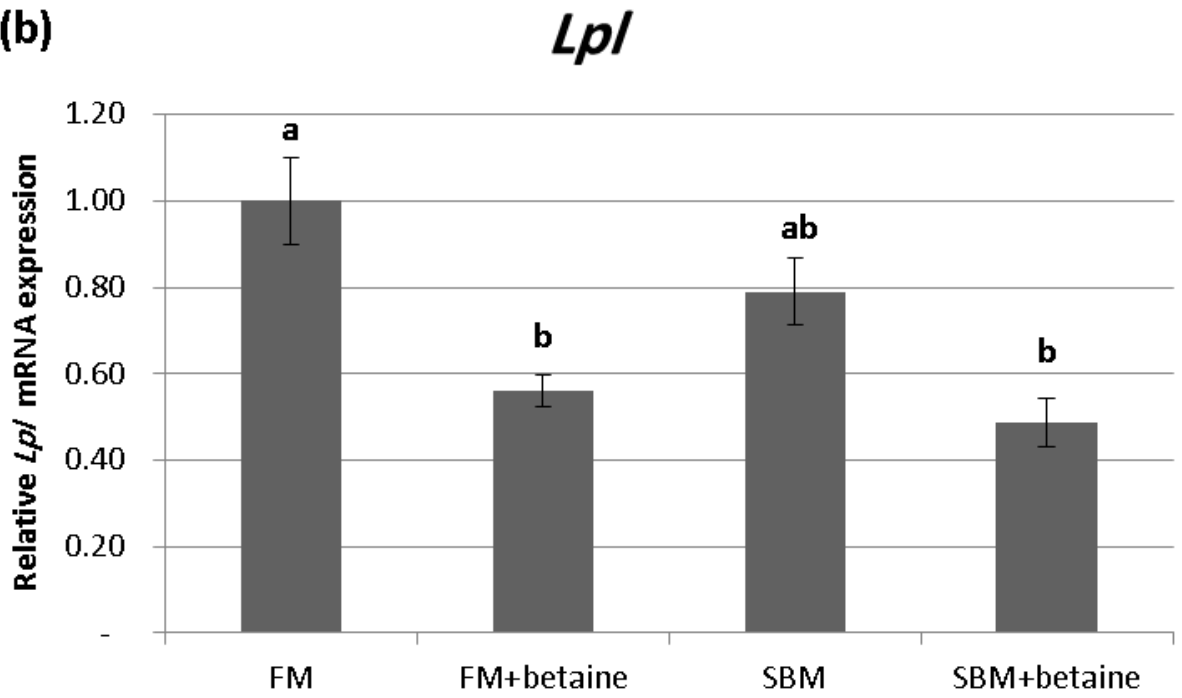

(c)
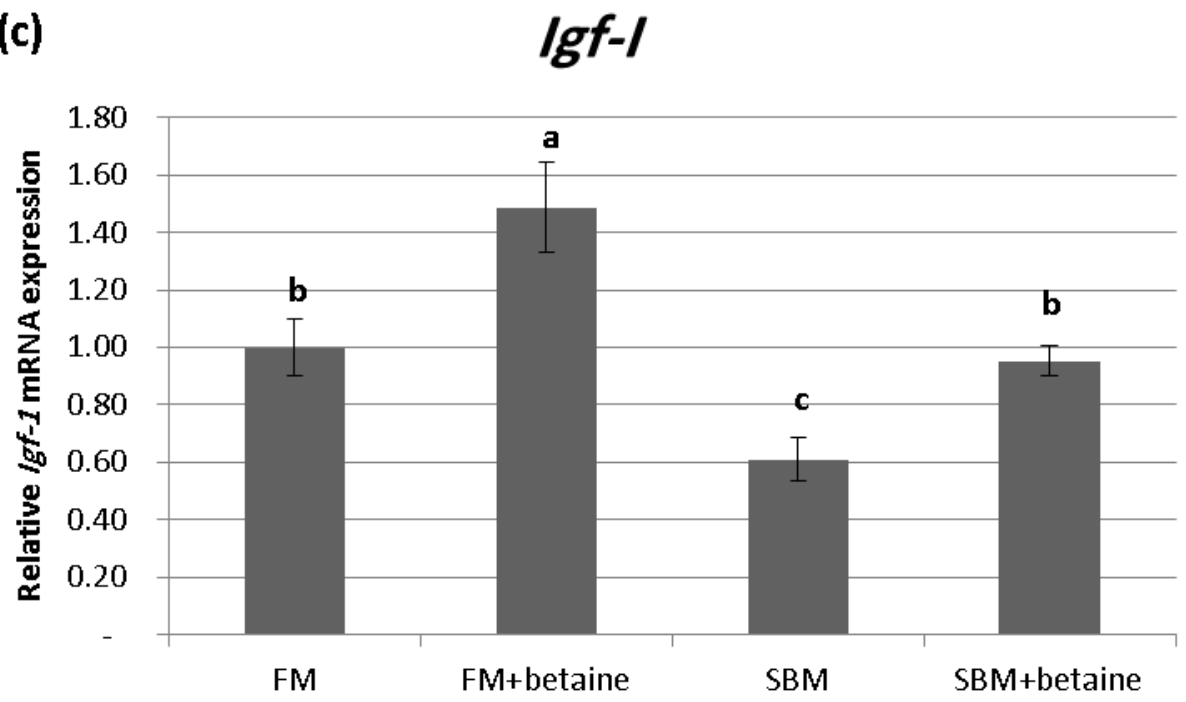

Figure 3: Effect of dietary betaine and different protein sources on mRNA level in liver (a) Fas: fatty acid synthetase; (b) Lpl: lipoprotein lipase; (c) Igf-1: insulin like growth factor-1 in Nile tilapia fed for 60 days. Values are expressed as the mean $\pm \mathrm{SE}(\mathrm{n}=3)$. Data with different letters on columns statistically differ $(P<0.05)$ 


\section{Discussion}

Growth is the fundamental key of energy loss and/or gains in the aquatic environment; which can be measured mainly by determination of the weight gain. Because of the expanding cost and untrustworthy supply of fish meal, various trials have been applied to redesign the growth performance and decline the production expenses of refined tilapia through substitution of fish meal with another plant protein sources. This was performed by usage of probiotics or prebiotics as protected dietary enhancements which have neither buildup in the refined fish nor unsafe effects for the fish customers $(14,15)$.

In the current study, fish fed FM showed higher BWG and FBW than SBM-based diets. The result is coincided with Fontainhas-Fernandes et al., (36) who reported that dietary FM was the main protein source showing the highest FBW and Khan et al. (37) who reported that inclusion of dietary FM up to $35 \%$ showed marked increase in the growth rate. This may be attributed to high protein quality of FM and its palatability. Betaine incorporation to SBM based diet improved feed intake relatively similar to FM. Similarly, betaine was used as a feeding stimulant in red sea bream (38), dover sole (39), European eel (40), Tilapia (31), juvenile grouper (41), and Chinese soft-shelled Turtle (42). This may indicate that betaine improved palatability of the diets which might be through stimulation of cephalic index induced by betaine smell and taste. Conversely, Hughes (43) suggested that betaine not affect the feed intake in Chinook Salmon Fry.

In addition, betaine incorporation in SBMbased diets not only increased FI but also growth performance compared to FM diet levels. Similar results were also reported in Indian major carp (25), rainbow trout (44), pike perch (45), and in tilapia fed $0.5 \%$ betaine (31). Kasper et al. (46) found that dietary betaine can spare the entire choline requirement in Nile tilapia in contrast with Vieira et al. (47). Regarding to the feed conversion ratio (FCR) which is considered as one of the most economic indicators, addition of betaine to FM or SBM-based diets decreased FCR. Diet based on SBM+ betaine achieved the same effect FM on feed efficiency. This result is similar to that reported by (25) who used $0.25 \%$ of betaine in carp fish diet, (48) who used $0.5 \%$ betaine in juvenile fresh water prawn fish and (26) who got the best FCR in channel cat fish (26). Decreased FCR might be attributed to the improvement of growth performance (31). Recently, Zou et al. (49) reported that feeding Nile tilapia with $0.6 \%$ betaine in diet containing high level of plant protein significantly lowered FCR. The beneficial effect of betaine on growth performance may be attributed to its feeding stimulant effect together with increased intestinal amylase and protease activities $(49,50)$. The positive effect of betaine on growth performance might be also due to alternation in the metabolism which needs further examination. However, the improvement of FCR in this study was due to the rapid growth rate which saves maintenance requirements.

Interestingly, betaine supplementation to SBM-based diets increased the body protein and decreased the fat content. This may be attributed to betaine role as a methyl donner, sparing methionine amino acid needed for protein synthesis. In addition, betaine plays a key role in synthesis of phosphatidyl choline, carnitine and creatine. Moreover, it was suggested that betaine role as a methyl donner enhances lipid metabolism, stimulating the hepatoprotective function resulting in prevention of the fatty liver (26). Furthermore, the incorporation of betaine at $0.4 \%$ in Allogynogenetic gibel carp diet resulted in lowering in the hepatopancreas, muscle and the whole body lipid content (51). Additionally, Wang et al. (27) reported that supplementation of dietary betaine decreased lipogenesis and increased fatty acids oxidation. The above evidence suggests that betaine incorporation into Nile tilapia diets provides the priority for protein synthesis which consumes smaller energy amounts than fat synthesis.

Assessment of intestinal healthiness including absorptive capacity and digestive 
functions through the height of intestinal villi, thickness of muscular layer and the number of goblet cells is an important morphometry indicator in case of evaluating different feed strategies in aquatic animals $(52,53)$. In the current study, betaine incorporation at $0.2 \%$ increased the intestinal villi length and number of goblet cells. Improving the intestinal absorptive and protective functions might be due to increased surface area available for absorption and/or due to secreted mucous from numerous goblet cells which has bactericidal effect through covering receptors of pathogens and keeping the integrity of intestinal epithelium $(54,55)$.

Lipid metabolism variations induced by betaine incorporation was monitored by changing in mRNA level of Fas which affects the synthesis of body fat and thereby affects the body fat accumulation (56). Fas and $\mathrm{Lpl}$ are considered key factors in lipid metabolism and fat deposition in the body (57). Current results revealed decreased Fas mRNA level associated with betaine incorporation in diet. Similar results were reported by Kim et al. (58) who revealed that protection of liver against steatosis could be occurred through supplementation of dietary betaine which decreased Fas and ACC (acetyl-CoA carboxylase) through affecting Forkhead Box O1 (FoxO1) binding peroxisome proliferator activated receptor gamma (PPAR $\gamma)$. Current results are similar to that reported in Allogynogenetic gibel carp (51). Additionally, hepatic $L p l$ mRNA level markedly decreased with supplementation of dietary betaine. Oku et al. (59) reported that the expression of $L p l$ was tissue specific therefore, the effect of dietary betaine on $\mathrm{Lpl}$ expression needs further examination for Nile tilapia different organs other than liver.

Igf-1 considers the major anabolic factor needed for growth (60). Igf-1 mRNA expression in the current study showed upregulation with addition of dietary betaine and down regulation when fish fed SBM-based diets without betaine which could subsequently reduce growth performance. Similar results were reported by Men et al. (61) who found that when fish fed on plant protein based diets at high level $(60 \%)$ showed lower hepatic Igf- 1 than that fed $30 \%$ in Japanese seabass.

\section{Conclusion}

From the obtained results, it could be concluded that betaine incorporation with $0.2 \%$ level to SBM-based diet improve palatability, growth performance, intestinal absorptive capacity, body protein on expense of lipid body accumulation, hepatic $I g f-1$ gene expression and reduce the lipogenesis through markedly decrease Fas and $L p l$ mRNA level in liver.

\section{Acknowledgement}

The authors are thankful to Dr. Mohsen Kamal, the technical director for Biochem company for his support in practical work in this manuscript and Dr. Safaa El-Sayed Abdo, lecturer of genetic and genetic engineering, Faculty of Veterinary Medicine, Kafrelsheikh University, Egypt, for her valuable cooperation.

\section{Conflict of interest}

The authors declare that they have no conflict of interest.

\section{References}

1. Hussain SM, Javed M, Javid A, Javid T, Hussain N. Growth responses of Catla catla, Labeo rohita and Cirrhina mrigala during chronic exposure of iron. Pak J Agric Sci. 2011; (1); 48:22530 .

2. Kumolu-Johnson CA, Ndimele PE. A review on post-harvest losses in Artisanal fisheries of some African countries. J. Fish. Aquat. Sci. 2011; 6: 365-78.

3. Rubbani B, Afzal M, Mubarik MS, Salim M, Hussain SM. Estimation of apparent digestibility coefficients of soybean meal based diets with different protein levels for Labeo rohita. Pak J Agric Sci. 2011; 1(48):231-5.

4. Fletcher GL, Shears MA, Goddard SV. Transgenic Fish for Sustainable Aquaculture. In: Sustainable Aquaculture: Food for the Future, Svennig, N., H. Reinertsen and M. New (Eds.). Balkema , Rotterdam, 1999; pp: 193-201

5. Mohamed HMA, Walaa FAE, Braeuning A, Hammad S. Detection of aflatoxin -producing fungi isolated from tilapia and fish feed. Excil $\mathrm{J}$. 2017; 16:1308-18. 
6. GAFRD. General authority for fish resources development. In: Fish Statistics Year Book. Cairo, Egypt: Ministry of Agriculture and Land Reclamation (2016).

7. El-Sayed AFM, Dickson MW, El-Naggar GO. Value chain analysis of the aquaculture feed sector in Egypt. Aquac 2015; 437: 92-101.

8. FAO. Fishery and Aquaculture Statistics Yearbook 2014. Rome, Italy: Food and Agriculture organization of the United Nations. ISSN 20706057 (2016).

9. El-Tholth M, Fornace K, Grace D, Rushton J, Häsler B. Characterisation of production, marketing and consumption patterns of farmed tilapia in the Nile Delta of Egypt. Food Policy 2015; 51: 131-43.

10. Nandlal S, Pickering T. Tilapia fish farming in Pacific Island countries. Vol. 1: Tilapia hatchery operation. Noumea, New Caledonia: Secretariat of the Pacific Community, 2004.

11. Sakai M. Current research status of fish immunostimulants. Aquac. 1999; 172: 63-92.

12. Merrifield DL, Dimitroglou A, Foey A, Davies SJ, Baker RTM. The current status and future focus of probiotic and prebiotic applications for salmonids. Aquac 2010; 302: 1-18.

13. Tacon AG, Metian M. Global overview on the use of fish meal and fish oil in industrially compounded aquafeeds: Trends and future prospects. Aquac, 2008; 285(1-4): 146-58.

14. Hai NV. Research findings from the use of probiotics in tilapia aquaculture: a review. Fish Shellfish Immunol 2015; 45: 592-7.

15. Ibrahem MD. Evolution of probiotics in aquatic world: Potential effects, the current status in Egypt and recent prospectives. J Adv Res 2015; 6: 765-91.

16. Leong-Seng L, Yong ASK, Shapawi R. Terrestrial animal-and plant-based ingredients as alternative protein and lipid sources in the diets for juvenile groupers: current status and future perspectives. Ann Res Rev Biol 2014;4(20): 3071.

17. Muñoz-Clares R, Valenzuela-Soto E. Betaine aldehyde dehydrogenases :evolution, physiological functions, mechanism, kinetics, regulation, structure, and stability. Adv. Protein Phys. Chem., Kerala, India, Res. Sign Post 2008; 279-302 .

18. Eklund M, Bauer E, Wamatu J, Mosenthin R. Potential nutritional and physiological functions of betaine in livestock. Nut Res Rev 2005;18(1): 31-48 .

19. Xue M, Cui Y. Effect of several feeding stimulants on diet preference by juvenile gibel carp
(Carassius auratus gibelio), fed diets with or without partial replacement of fish meal by meat and bone meal. Aquac 2001; 198(3-4):281-92.

20. Fekrandish H, Abedian A, Matin Far A, Monfard N, Dehghani A. Influence of betaine and methionine in the diet for stimulating food intake of indian white shrimp (Fenneropenaeus indicus). Pajouhesh and Sazandegi. 2007.

21. Papatryphon E, Soares Jr JH. Optimizing the levels of feeding stimulants for use in high-fish meal and plant feedstuff-based diets for striped bass, Morone saxatilis. Aquac 2001;202(3-4): 279-88.

22. Hanson AD, Rathinasabapathi B, Rivoal J, Burnet M, Dillon MO, Gage DA. Osmoprotective compounds in the Plumbaginaceae: a natural experiment in metabolic engineering of stress tolerance. Proceed Nat Acad Sci 1994; 91(1):306-10 .

23. De Vooys C, Geenevasen J. Biosynthesis and role in osmoregulation of glycine-betaine in the Mediterranean mussel Mytilus galloprovincialis LMK. Comparative Biochemistry and Physiology Part B: Biochemistry and Molecular Biology, 2002; 132(2): 409-14 .

24. Sheard N, Zeisel S. Choline: an essential dietary nutrient? Nutrition (Burbank, Los Angeles County, Calif.), 1989; 5(1):1-5.

25. Shankar R, Murthy S, Pavadi P, Thanuja $K$. Effect of betaine as a feed attractant on growth, survival, and feed utilization in fingerlings of the Indian major carp, Labeo rohita. Isr. J. Aquac Bamidgeh 2008; 60(2): 95-9.

26. $\mathrm{Wu} \mathrm{G}$, Davis DA. Inter-relationship among methionine, choline, and betaine in channel catfish (Ictalurus punctutus). J World Aquac Soc 2005; 36(3): 337-45.

27. Wang L, Chen L, Tan Y, Wei J, Chang Y, Jin T, Zhu H. Betaine supplement alleviates hepatic triglyceride accumulation of apolipoprotein E deficient mice via reducing methylation of peroxisomal proliferator-activated receptor alpha promoter. Lipids in health and disease 2013; 12(1): 34 .

28. Zhang W, Wang LW, Wang LK, Li X, Zhang H, Luo LP,. . . Gong ZJ. Betaine protects against high-fat-diet-induced liver injury by inhibition of high-mobility group box 1 and Toll-like receptor 4 expression in rats. Dig Dis \& sci 2013; 58(11): 3198-206.

29. He S, Zhao S, Dai S, Liu D, Bokhari SG.. Effects of dietary betaine on growth performance, fat deposition and serum lipids in broilers subjected to chronic heat stress. Animal Science J 2015; 86(10): 897-903 . 
30. Leng Z, Fu Q, Yang X, Ding L, Wen C, Zhou Y. Increased fatty acid $\beta$-oxidation as a possible mechanism for fat-reducing effect of betaine in broilers. Animal Science J 2016; 87(8):100510.

31. Luo Z, Tan XY, Liu XJ, Wen H. Effect of dietary betaine levels on growth performance and hepatic intermediary metabolism of GIFT strain of Nile tilapia Oreochromis niloticus reared in freshwater. Aquac Nut 2011; 17(4):361-7 .

32. Livak KJ, Schmittgen TD. Analysis of Relative Gene Expression Data Using Real-Time Quantitative PCR and the 2- $\Delta \Delta$ CT Method. Methods 2001; 25: 402-8.

33. Tian J, Wu F, Yang CG, Jiang M, Liu W, Wen H. Dietary lipid level impact lipoprotein lipase, hormone-sensitive lipase and fatty acid synthetase gene expression in three tissue of adult GIFT strain of Nile Tilapia, Oreochromis niloticus. Fish Physiol Biochem 2015; 41:1-18.

34. Costa LS, Rosa PV, Fortes-Silva R, Sánchez-Vázquez FJ, López-Olmeda JF. Daily rhythms of the expression of genes from the somatotropic axis: the influence on tilapia (Oreochromis niloticus) of feeding and growth hormone administration at different times. Comparative Biochemistry and Physiology Part C: Toxicology \& Pharmacology 2016; 181: 27-34.

35. Qiang J, He J, Yang H, Wang H, Kpundeh M, Xu P, Zhu Z. Temperature modulates hepatic carbohydrate metabolic enzyme activity and gene expression in juvenile GIFT tilapia (Oreochromis niloticus) fed a carbohydrate-enriched diet. J Therm Biol 2014; 40: 25-31.

36. Fontainhas-Fernandes A, Gomes E, ReisHenriques MA, Coimbra J. Replacement of fish meal by plant proteins in the diet of Nile tilapia: digestibility and growth performance. Aquacult Int 1999; 7(1): 57-67.

37. Khan M, Siddique M, Zamal H. Replacement of fish meal by plant protein sources in Nile tilapia (Oreochromis niloticus) diet: growth performance and utilization. Iran $\mathbf{J}$ Fish Sci 2013;12(4): 864-72.

38. Goh Y, Tamura T. Effect of amino acids on the feeding behaviour in red sea bream. Comparative Biochemistry and Physiology Part C: Comparative Pharmacology 1980; 66(2):225-9 .

39. Mackie A, Mitchell A. Further studies on the chemical control of feeding behaviour in the Dover sole, Solea solea. Comp Biochem Physiol Part A: Physiology 1982; 73(1): 89-93 .

40. Mackie A, Mitchell A. Studies on the chemical nature of feeding stimulants for the juvenile European eel, Anguilla anguilla (L.). J Fish Biol 1983; 22(4): 425-30 .

41. Lim LS, Chor WK, Tuzan AD, Shapawi $\mathrm{R}$, Kawamura G. Betaine is a feed enhancer for juvenile grouper (Epinephelus fuscoguttatus) as determined behaviourally. J Appl Ani Res 2016; 44(1): 415-8.

42. Sun $\mathrm{CX}, \mathrm{Xu} \mathrm{WN}$, Zhang DD, Li XF, Li PF, Jiang GZ, Liu WB. Different preference is modulated by the feeding stimulants supplementation in different Chinese soft-shelled turtle (Pelodiscus sinensis) basic diets. Aquac Nut 2018; 24(1): 195-203.

43. Hughes SG. Single feeding response of chinook salmon fry to potential feed intake modifiers. Prog Fish-Cult 1993; 55(1): 40-2 .

44. Tiril SU, Alagil F, Yagci FB, Aral O. Effects of betaine supplementation in plant protein based diets on feed intake and growth performance in rainbow trout (Oncorhynchus mykiss). Isr. J Aquace - Bamidgeh 2008; 60(1): 57-64.

45. Zakipour Rahimabadi E, Akbari M, Arshadi A, Effatpanah E. Effect of different levels of dietary Betaine on growth performance, food efficiency and survival rate of pike perch (Sander lucioperca) fingerlings. Iran J Fish Sci. 2012; 11: 902-10.

46. Kasper CS, White M, Brown P. Betaine can replace choline in diets for juvenile Nile Tilapia, Oreochromis niloticus. Aquac 2002; 205 : 119-26.

47. Vieira I, Cyrino JEP, Pezzato LE. Colina e betaína em rações purificadas na nutrição da tilápia do Nilo (Oreochromis niloticus). Sci Agric 2001; 675-80.

48. Felix N, Sudharsan M. Effect of glycine betaine, a feed attractant affecting growth and feed conversion of juvenile freshwater prawn Macrobrachium rosenbergii. Aquac Nut 2004; 10:193-.

49. Zou Q, Huang Y, Cao J, Zhao H, Wang G, Li Y, Pan Q. Effects of four feeding stimulants in high plant-based diets on feed intake, growth performance, serum biochemical parameters, digestive enzyme activities and appetite-related genes expression of juvenile GIFT tilapia (Oreochromis sp.). Aquac Nut 2017; 23(5): 1076-85.

50. Srinivas D. Effect of G-probiotic on growth, body composition and survival of giant freshwater prawn, Macrobrachium rosenbergii (de Man) and Indian Major Carp, Labeo rohita (Ham), MF Sc. Thesis submitted to University of Agricultural Sciences 2000; 113. 
51. Dong X, Xue W, Hua J, Hang Y, Sun L, Miao S, Wei W, Wu X, Du X. Effects of dietary betaine in Allogynogenetic gibel carp (Carassius auratus gibelio): Enhanced growth, reduced lipid deposition and depressed lipogenic gene expression. Aquac Res 2018; 49: 1967-72.

52. Pirarat N, Pinpimai K, Endo M, Katagiri T, Ponpornpisit A, Chansue N, Maita M. Modulation of intestinal morphology and immunity in nile tilapia (Oreochromis niloticus) by Lactobacillus rhamnosus GG. Res Vet Sci 2011; 91(3): 92-7.

53. Khojasteh SMB. The morphology of the post-gastric alimentary canal in teleost fishes: a brief review. Int J Aquat Sci 2012; 3(2): 71-88.

54. Ringø E, Olsen RE, Mayhew TM, Myklebust R. Electron microscopy of the intestinal microflora of fish. Aquac 2003; 227(1-4): 395-415.

55. Smirnov A, Perez R, Amit-Romach E, Sklan D, Uni Z. Mucin dynamics and microbial populations in chicken small intestine are changed by dietary probiotic and antibiotic growth promoter supplementation. J Nut 2005; 135(2): 18792.

56. Leng X, Wu X, Tian J, Li X, Guan L, Weng D. Molecular cloning of fatty acid synthase from grass carp (Ctenopharyngodon idella) and the regulation of its expression by dietary fat level. Aquac Nut 2012; 18: 551-8.
57. Albalat A, Saera-Vila A, Capilla E, Gutiérrez J, Pérez-Sánchez J, Navarro I. Insulinregulation of lipoprotein lipase $(L p l)$ activity and expression in gilthead sea bream (Sparus aurata). Comparative Biochemistry and Physiology Part B: Biochem Mol Biol 2007; 148(2): 151-159.

58. Kim DH, Lee B, Kim MJ, Park MH, An HJ, Lee EK, Chung KW, Park JW, Yu BP, Choi JS. Molecular Mechanism of Betaine on Hepatic Lipid Metabolism: Inhibition of Forkhead Box O1 (FoxO1) Binding to Peroxisome Proliferator-Activated Receptor Gamma (PPAR $\gamma$ ). J Agr food chem 2016; 64: 6819-6825.

59. Oku H, Koizumi N, Okumura T, Kobayashi T, Umino T. Molecular characterization of lipoprotein lipase, hepatic lipase and pancreatic lipase genes: effects of fasting and refeeding on their gene expression in red sea bream Pagrus major. Comp Biochem Physiol B: Biochem Mol Biol 2006; 145:168-178.

60. Thissen JP, Underwood LE, Ketelslegers JM. Regulation of Insulin like Growth Factor-I in Starvation and Injury. Nut Rev 1999; 57(6): $167-$ 176.

61. Men K, Ai Q, Mai K, Xu W, Zhang Y, Zhou H. Effects of dietary corn gluten meal on growth, digestion and protein metabolism in relation to Igf-I gene expression of Japanese seabass, Lateolabrax japonicus. Aquac 2014; 428: 303-9. 